
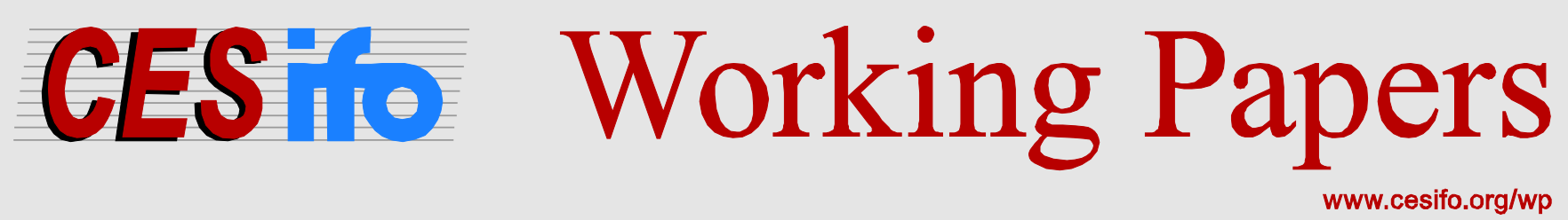

\title{
Electoral Cycles in MPs' Salaries: Evidence from the German States
}

\author{
Björn Kauder \\ Manuela Krause \\ Niklas Potrafke
}

CESIFO WORKING PAPER NO. 6028

CATEgory 2: Public CHOICE

August 2016
An electronic version of the paper may be downloaded
- from the SSRN website:
- from the RePEc website:
- from the CESifo website:
wWw.SSRN.com
www.RePEc.org
www.CESifo-group.org/wp




\title{
Electoral Cycles in MPs' Salaries: Evidence from the German States
}

\begin{abstract}
Members of parliament (MPs) often decide on their own salaries. Voters dislike self-serving politicians, and politicians are keen to gratify their voters. In line with the political business cycle theories, politicians thus may well delay deciding on increases in salaries until after elections. We investigate electoral cycles in the salary increases of German state MPs. Using data for 15 states over the period 1980-2014, the results do not show that decisions on increases in MPs' salaries were influenced by elections. In fact, MPs' salaries increased by 0.30 to 0.37 percent when employees' salaries increased by one percent. Politicians can increase their salaries at any point of time in the legislative period: understanding that all politicians benefit from an increase in salaries, voters may only be disenchanted with politics in general, without punishing individual incumbent parties.
\end{abstract}

JEL-Codes: D720, H700, A130.

Keywords: electoral cycles, political business cycles, election-motivated politicians, MPs' salaries, rent extraction.

\author{
Björn Kauder* \\ Ifo Institute - Leibniz Institute for \\ Economic Research \\ at the University of Munich \\ Poschingerstrasse 5 \\ Germany-81679 Munich \\ kauder@ifo.de
}

\author{
Manuela Krause \\ Ifo Institute - Leibniz Institute for \\ Economic Research \\ at the University of Munich \\ Poschingerstrasse 5 \\ Germany - 81679 Munich \\ krause@ifo.de
}

\author{
Niklas Potrafke \\ Ifo Institute - Leibniz Institute for \\ Economic Research \\ at the University of Munich \\ Poschingerstrasse 5 \\ Germany-81679 Munich \\ potrafke@ifo.de
}

\footnotetext{
*corresponding author
} 


\section{Introduction}

In many countries, the members of parliament (MPs) decide on their own salaries (e.g., Mause 2014). Having decision-making authority over their own salaries may facilitate political benefits or political rent extraction, because increases in salaries are likely to be generous when MPs decide on their own salaries. The possibility of rent extraction provides self-serving politicians with incentives for rent creation and rent sharing (Hillman 2015). Voters dislike self-serving politicians and may accuse politicians of impropriety with taxpayers' money when increases in salaries appear to be too high. Because politicians are keen to gratify their voters and the media often discusses adjustments of the salaries of politicians, politicians ponder when to increase their salaries, and may, thus, delay decisions on increases in salaries until after elections. The self-induced increases of the salaries of MPs may be a prime example for electoral cycles. ${ }^{1}$

The political business cycle theories describe that election-motivated politicians pursue expansionary policies before elections. Election-motivated politicians may, for example, increase public spending, and especially public spending that is visible to voters, or they may decrease taxes (Nordhaus 1975, Rogoff and Sibert 1988). Many empirical studies portray how election-motivated politicians manipulate economic policy-making. ${ }^{2}$ In Germany, electoral cycles occur on all levels of government, and particularly on the state level: elections have been shown to influence the hiring of teachers and police officers, cultural policies, deficit spending, social security expenditure, active labor market policies, fiscal forecasts, hospital beds, firms' investments, and business perceptions (Tepe and

\footnotetext{
${ }^{1}$ Salaries are certainly only one part of the remuneration of politicians (see Arnim 1998 and 2010); increases in other parts (such as pensions) are, however, less visible and, thus, may be less likely to show electoral effects.

${ }^{2}$ On political budget cycles in the European Union, see Efthyvoulou (2012); on political budget cycles in a larger set of countries, see de Haan and Klomp (2013) and Klomp and de Haan (2013). Katsimi and Sarantides (2012), Bove et al. (in press), Köppl-Turyna et al. (2016), and Castro and Martins (2016) investigate how elections influence budget composition and Osterloh (2012) and Potrafke (2012a) examine how elections influence economic performance. Incumbents increased the growth in public health expenditure and were active in creative accounting before elections (Potrafke 2010, Herwartz and Theilen 2014, and Reischmann 2016). Foreign reserves in democracies were higher before elections (Jäger 2016). Transparency may mitigate political budget cycles (Benito and Bastida 2009). On public investment and re-election prospects, see Katsimi and Sarantides (2015).
} 
Vanhuysse 2009, 2013, and 2014, Schneider 2010, Mechtel and Potrafke 2013, Kauder et al. 2016, Potrafke and Roesel 2016, Riem 2016a and 2016b). On the municipal level, elections have been shown to influence total spending, local business tax rates, and public administration decisions (Foremny et al. 2014, Foremny and Riedel 2014, Garmann in press). Evidence about electoral cycles on the federal level suggests that elections influence centralized wage negotiations in the public sector (Matschke 2003), but not macroeconomic indicators and social policies (Berger and Woitek 1997, Potrafke 2012b). ${ }^{3}$

How large should politicians' salaries optimally be? The literature concludes that high salaries for politicians may be justified for two reasons: high salaries for politicians may improve the performance of politicians due to an incentive effect, and it is conceivable that higher wages attract better candidates (Besley 2004, Caselli and Morelli 2004, Messner and Polborn 2004, Mattozzi and Merlo 2008, Keane and Merlo 2010, Bordignon et al. 2013). Indeed, empirical studies suggest that higher wages attracted more educated candidates in Italy (Gagliarducci and Nannicini 2013) and also increased the quality of female candidates in Finland (Kotakorpi and Poutvaara 2011). In the European parliament, by contrast, increased salaries yielded less experienced newly-elected politicians (Braendle 2015). Evidence on how salaries influenced efforts in the European parliament is mixed (Fisman et al. 2013, Mocan and Altindag 2013, Braendle 2015). ${ }^{4}$

In the German states, MPs decided annually on their own salaries, particularly in the 1980s, 1990s, and 2000s (currently, the salaries of MPs are coupled with employees' salaries

\footnotetext{
3 In the United Kingdom, elections influenced MPs' outside activities (Geys 2013). In the United States, bureaucrats' salaries increased more in election years (Borjas 1984). See Vadlamannati (2015) on electoral cycles in anti-corruption policies. Political cycles may be influenced by term limits (Klein and Sakurai 2015, Dalle Nogare and Kauder 2016) and globalization (Efthyvoulou 2011).

${ }^{4}$ A political office may also give rise to private returns (Eggers and Hainmueller 2009, Querubin and Snyder 2013, Fisman et al. 2014, Kotakorpi et al. 2015). When politicians earn these private returns during an official political term, returns may influence parliamentary effort (Gagliarducci et al. 2010, Arnold et al. 2014, Geys and Mause in press). See Peichl et al. (2013) on how the salaries of politicians and private sector executives differ in Germany; Elliott et al. (2005) compare the public and private sector pay in the United Kingdom. The education of voters and US governors' salaries have been shown to be negatively correlated (Mirhosseini 2016). On the nexus between institutional restrictions and bureaucratic rents see Luechinger et al. (2014); on rent extraction see also Kauder and Potrafke (2015 and 2016).
} 
in most states). By combining the two strands of literature on electoral cycles and the salaries of politicians, we investigate whether electoral cycles occurred in the salaries of German state MPs. The fact that election dates vary across the German states means that we can disentangle the effect of elections from common trends. Using data for 15 German states over the period 1980-2014, the results do not indicate that elections influenced when MPs decided to increase their salaries.

\section{Institutional backdrop}

\subsection{MPs' salaries in the German states}

The state politicians decide on their salaries, and typically codify adjustments in specific acts (“Abgeordnetengesetz"). ${ }^{5}$ Several reforms changed the way how salaries are calculated. In the 1950s and 1960s, state MPs' salaries were often coupled with the salaries of the members of the federal parliament (Bundestag). In 1975, the Supreme Court emphasized that MPs should be financially independent and adjudicated that the (state) parliaments have to decide discretionarily on MPs' salaries (see Arnim 1975). The states accordingly revised the way salaries were adjusted and thus had a large leeway in deciding upon salaries. After the reunification, the East German states mainly adopted the procedures of the West German states, with the exception of Thuringia, which decided to index MPs' salaries to employees' salaries.

In 1996, Bavaria was the first state to follow Thuringia's lead to index MPs' salaries. Most other states followed in the early 2000s and no longer adjust MPs' salaries discretionarily (only four states still have not indexed salaries of their politicians). At the beginning of every legislative period, the state parliaments decide on how to index MPs' salaries, which then increase annually. In most states, the indexation links the development of MPs' salaries to the growth of employees' salaries (in the private and public sector); some states include

\footnotetext{
${ }^{5}$ See Weichold (2001) on the historical development of how MPs' salaries were decided upon. Gersbach (2009) examines how welfare is affected when candidates offer their individual salaries competitively.
} 
further indicators such as inflation. The statistical office of each state reports the figures to the president of the state parliament, who then publishes the new level of MPs' salaries in a law gazette. Lower Saxony is the only state in which the parliament has to vote on the adjustment of MPs' salaries every year; in the other states the parliament is not involved annually.

\subsection{State elections}

Elections in the German states take place every five years. The only exceptions are Hamburg and Bremen, where elections take place every four years. In the past even more states held elections every four years. Parliaments may also call early elections: out of 86 elections in our sample, 13 were early elections. In most states, voters cast two votes in a personalized proportional representation system. The first vote determines which candidate is to obtain the direct mandate in one of the electoral districts with a relative majority. With the second vote, voters select an individual party. The parties obtain a number of the seats in parliament that corresponds to the party's second vote share. Candidates voted into the parliament with the first vote (direct mandate) obtain their seats first. Candidates from party lists obtain the remaining seats.

\section{Empirical analysis}

\subsection{Descriptive statistics}

We use data on MPs' nominal salaries from state law gazettes and further data from the federal and the states' statistical offices, the state election administrators, the German Bundestag, and the German Council of Economic Experts. We use annual data over the period 1980-2014 for the West German states and over the period 1991-2014 for the East German states. In some states our data end earlier, because these states have started to index MPs' salaries (see section 2.1). We exclude Thuringia, because MPs' salaries in Thuringia are coupled with the general development of wages since 1990. We also exclude increases in 
salaries of over 20 percent, which represent increases after reforms in parliament such as adjusting the taxation of salaries or transforming a part-time parliament into a full-time parliament. The sample includes 15 states and 367 observations. ${ }^{6}$

Figure 1 shows the average increase in MPs' nominal salaries after and before elections. MPs' salaries increased on average by 1.96 percent when it was the first increase within the 365 days after an election; and by 2.07 percent when it was the last increase within the 365 days before an election. At other times of the legislative period, MPs' salaries increased on average by 2.54 percent. T-tests on means indicate that post-election and preelection increases are both not significantly different from increases at other points in time.

To arrive at more precise inferences about the nexus between points of time in a legislative period and increases in salaries, the left part of Figure 2 shows the result of a nonparametric regression of increases in salaries on the share of a legislative period that has passed, using kernel-weighted local polynomial smoothing; the right part shows a semiparametric regression including all our (parametric) control variables (see Boone et al. 2014, 404-407). Both panels corroborate the evidence from Figure 1 and suggest that MPs' salaries increased somewhat less at the beginning and at the end of a legislative period. The regular pattern of local minima arises from our coding of pay freezes (see footnote 6).

Table 1 shows descriptive statistics. Table 2 shows the correlation coefficients between our main variables. Increases in MPs' salaries are hardly correlated with the postelection and the pre-election dummy variables (correlation coefficients: -0.05 and -0.04 ) and with the number of days since the last election (0.02). Increases in MPs' salaries and in lagged employees' salaries are somewhat correlated (0.34) - see also Figure 3.

\footnotetext{
${ }^{6}$ In some cases, salaries were not increased. To define the dates on which these pay freezes were decided upon, we use the average day on which increases in salaries were decided upon in other years in the respective state.
} 


\subsection{Empirical strategy}

The baseline panel-data model has the following form:

$$
\begin{gathered}
{\text { Increase in MPs' } \text { salaries }_{i t}=\beta \text { Post-election period }}_{i t}+\gamma \text { Pre-election period }_{i t} \\
+\delta \text { Increase in employees' salaries } \text { It- }_{1}+\varepsilon \text { Deficit ratio }_{i t-1} \\
+\zeta \text { Government ideology }_{i t}+\varphi \text { Seat share government }{ }_{i t}+\eta_{i}+\tau_{t}+u_{i t}
\end{gathered}
$$

$$
\text { with } \mathrm{i}=1, \ldots, 15 ; \mathrm{t}=1, \ldots, 35
$$

where Increase in MPs' salaries $_{i t}$ measures the increase in MPs' nominal salaries in state $i$ in year $t$ (growth rate). The dummy variable Post-election period it $_{\text {assumes }}$ the value one for the first increase in salaries within the 365 days after an election and zero otherwise. The dummy variable Pre-election period $_{i t}$ assumes the value one for the last increase in salaries within the 365 days before an election. ${ }^{7}$ The reference category is thus the period between the post- and the pre-election period (please note that predetermined elections are exogenous explanatory variables). In alternative specifications, we use a variable measuring the number of days since the last election divided by the total length of the legislative period (Share of legislative

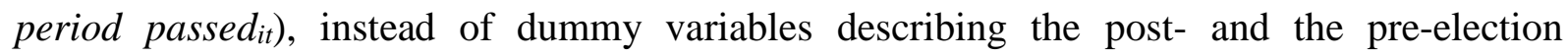
periods. ${ }^{8}$ Increase in employees' salaries it-1 measures the extent to which the salaries of employees in the private and public sector increased in the year before (see also Di Tella and Fisman 2004); please note that we consider nominal values of salaries and thus capture both increases in real salaries and inflation. The variable Deficit ratio it- $1_{1}$ measures how public debt has increased relative to GDP in state $i$ in year $t$ - 1 . The variable Government ideology assumes the value one when a left-wing government was in office, the value 0.5 for a center government, and the value zero for a right-wing government (e.g., Kauder and Potrafke 2013,

\footnotetext{
${ }^{7}$ In the case of early elections, we consider an increase in salaries only as belonging to the pre-election period when early elections were known at that point of time.

${ }^{8}$ In the case of early elections, we consider the regular length of a legislative period when salaries were increased before early elections were called, and the actual length when salaries were increased after early elections were called.
} 
Potrafke et al. 2016). It is conceivable that politicians increase their salaries more when they enjoy a large majority of seats in parliament (see Benito et al. 2014 and Svaleryd and Vlachos 2009). Seat share government $t_{i}$ thus measures the number of seats of the governing parties relative to all seats in parliament. $\eta_{i}$ is a fixed state effect; $\tau_{t}$ is a fixed time effect; $u_{i t}$ is the error term. In some specifications, we include Increase in federal MPs' (nominal) salariest-1, which only varies over time and not over states, instead of fixed time effects. We estimate a fixed-effects model with standard errors robust to heteroskedasticity (Huber/White/sandwich standard errors - see Huber 1967 and White 1980).

\subsection{Regression results}

Table 3 shows the regression results excluding fixed time effects. In discussing the results, we focus on our preferred specification including all control variables in column (3). The coefficients of the dummy variables Post-election period and Pre-election period are negative and insofar corroborate the graphical evidence, but lack statistical significance. Increases in MPs' salaries are positively correlated with increases in employees' salaries. The effect attains statistical significance at the 1 percent level and indicates that a one percent increase in employees' salaries in the year before gives rise to a 0.30 percent increase in MPs' salaries. The effect is small; but it is important to note that the constant shows a significant effect, indicating that MPs' salaries increased by 2.65 percent per year (conditional on the other explanatory variables) and politicians thus smooth increases in their salaries over time. Our other control variables (lagged) Deficit ratio, Government ideology and (lagged) Increase in federal MPs' salaries do not turn out to be statistically significant. The effect of Seat share government indicates that powerful governments increase MPs' salaries less; the effect, however, is only statistically significant at the 10 percent level.

In Table 4 we include fixed time effects and thus cannot include Increase in federal MPs' salaries, because this variable does not vary across states. Inferences regarding the elec- 
tion period dummies and the effect of employees' salaries do not change. Including fixed time effects, however, renders the effect of Seat share government to lack statistical significance.

Table 5 shows the results (excluding fixed time effects) when we use the Share of legislative period passed as main explanatory variable, describing a legislative period's share of time that has passed at the time when MPs decided to increase their salaries. The effect lacks, however, statistical significance. The coefficient estimate of Increase in employees' salaries corroborates our result from Tables 3 and 4 and indicates that increases in MPs' and (lagged) employees' salaries are positively correlated. Inferences do not change when we include a quadratic term of Share of legislative period passed (columns 4-6): the specifications indicate an inverted u-shaped relationship between the share of a legislative period that has passed and increases in MPs' salaries, and insofar corroborate the graphical evidence from Figure 2; the effects lack, however, statistical significance at conventional levels. The effects of Share of legislative period passed and its quadratic term lack also statistical significance when we include fixed time effects in Table 6.

As a placebo test, we include in Table 7 also the indexed years in our sample. The sample size thus increases to 478 observations. Inferences regarding the election period dummies and the effect of the continuous time variable Share of legislative period passed do not change independent of including or excluding fixed time effects. This holds also for employees' salaries.

In Table 8 we run the regressions for the indexed years only (111 observations). The coefficients of the election period dummies and the employees' salaries lack statistical significance. The effect of the variable Share of legislative period passed and its quadratic term also lack statistical significance. The variable Government ideology is only statistically significant in one specification. 


\subsection{Robustness tests}

We submitted our results to rigorous robustness tests using different specifications of our regressions and different samples. None of these robustness tests indicates any severe fragility in our results.

We estimated our baseline panel-data model with a fixed-effects estimator. Many observations of increases in salaries, however, are zero; therefore, a Tobit model may be more suitable. When we use a Tobit cross-section estimator (a parametric conditional fixed-effects Tobit panel estimator is not available), the results indicate that MPs decided to increase salaries less after elections, and in some specifications also less before elections. The effect of the continuous time variable Share of legislative period passed is statistically significant when we also include its quadratic term. The coefficients of both variables indicate that politicians increase their salaries in the middle of the legislative period. This corroborates the graphical evidence from Figure 2. Inferences compared to our baseline model do not change when we use a random-effects model. Inferences with a random-effects Tobit model are similar to those with a Tobit cross-section estimator.

As an alternative to considering the growth rate of MPs' salaries as the dependent variable, we used a binary variable that assumes the value one when salaries were increased and zero otherwise. Running a probit or logit model, the results show that the probability of an increase in salaries was lower after and before elections. Given the results in Tables 3 and 4, this indicates that positive increases in MPs' salaries were higher after and before elections. In fact, if increases were positive, they were on average 4.69 percent after an election and 4.96 percent before an election, but only 4.31 percent at other times. The effect of the continuous time variable Share of legislative period passed is statistically significant when we also include its quadratic term.

We also tested if only decisions on extraordinary increases in salaries were influenced by electoral cycles. To this end, we used a binary variable as the dependent variable that 
assumes the value one when MPs' salaries were increased more than (lagged) employees' salaries. Running a probit or logit model, the results show that the probability of MPs' salaries increasing more than those of employees was lower before and after elections.

We tested whether inferences change when we include the lagged level of MPs' salaries to control for mean reversion. The results show that a higher lagged level of MPs' salaries decreased the growth rate of salaries when we do not include fixed time effects, but still do not show that elections influenced increases in salaries.

In constructing our main explanatory variables Post-election period and Pre-election period, we captured increases in salaries within the 365 days after or before an election. Inferences do not change when we alternatively capture increases in salaries within 0.5 years or 1.5 years after or before an election. Our alternative main explanatory variable Share of legislative period passed is defined as the number of days since the last election divided by the total length of the legislative period. Inferences do not change when we use the number of days since the last election (without dividing by the length of the legislative period) as an explanatory variable.

We tested whether inferences change when we include Increase in employees' salaries, Deficit ratio and Increase in federal MPs' salaries from the respective year and not in lags. The results show that Increase in employees' salaries does not turn out to be statistically significant when we include fixed time effects. The effect, however, remains statistically significant when we exclude fixed time effects. The coefficient of Deficit ratio is positive and statistically significant in all specifications. The effect of Increase in federal MPs' salaries is statistically significant only in some specifications. The election period dummy variables are not significant in all specifications. The coefficient of the continuous time variable Share of legislative period passed is statistically significant only when we include its quadratic term and when we exclude fixed time effects. We also tested whether inferences change when we use Increase in employees' salaries and Increase in federal MPs' 
salaries in real terms and include lagged inflation as another control variable to disentangle the effects of real salaries' increases and inflation. Inferences do not change.

Our measure of employees' salaries includes net salaries, income tax, and the social security contributions of employees. Inferences regarding electoral cycles and the effect of increases in employees' salaries do not change when we use an alternative measure of employees' salaries that also includes the social security contributions of employers. Inferences regarding electoral cycles also do not change when we replace the (lagged) growth in employees' salaries with the (lagged) growth in GDP, which is statistically significant at the 10 percent level only in some specifications. To describe the power of a government, we used the seat share of the governing parties in parliament. Inferences regarding electoral cycles and the effect of the power of a government do not change when we use the vote share of the governing parties divided by the vote share of all parties represented in parliament.

We examined whether our results are driven by individual years or individual states. When we exclude individual years or states, one at a time (Jackknife test), the results do still not show electoral cycles in MPs' salaries when we use the electoral period dummies or the share of the legislative period that has passed as main explanatory variables. When we include the quadratic term of Share of legislative period passed, the results indicate that MPs' salaries increased less after and before elections when we exclude the years 1985 or 1993, or the state Baden-Wuerttemberg.

Politicians in the eastern German states may well differ from politicians in their western German counterparts. The results of separate regressions for eastern German and western German states do not show electoral cycles in MPs' salaries.

It is conceivable that electoral cycles occur only under some type of government ideology. We thus estimated our model separately for left-wing, right-wing, and center governments. The results do not show electoral cycles in MPs decisions on increases in salaries. 


\section{Conclusion}

In the German states, MPs decided annually on their own salaries, particularly in the 1980s, 1990s, and 2000s. The German states are therefore an excellent laboratory for electoral manipulation. We investigated whether elections influence increases in MPs' salaries. The results do not show (robust) evidence for electoral cycles in decisions on increases in MPs' salaries; nor do government ideology and the power of the government influence MPs' salaries. We do find, however, that increases in MPs' salaries are positively correlated with increases in employees' salaries.

Why is it that increases in MPs' salaries do not show an electoral cycle? When MPs increase their salaries, they do so for all MPs, not only for the MPs of the governing parties. To be sure, politicians from the governing parties may well be punished for having initiated and having voted for increases in salaries. Understanding that all politicians benefit from an increase in salaries, voters, however, may only be disenchanted with politics in general, without punishing individual parties. Politicians can then increase their salaries at any point of time without having to expect a negative voter reaction. This also explains why governments with a large majority in parliament do not increase salaries more than governments with a fragile majority. 


\section{Acknowledgments}

We would like to thank Hans Herbert von Arnim, Paul Hufe, and seminar/conference participants at the Public Choice Society's Annual Meeting (Fort Lauderdale 2016), the Spring Meeting of Young Economists (Lisbon 2016), the Meeting of the Association for Public Economic Theory (Rio de Janeiro 2016), the University of Munich, and the Ifo Institute for their helpful comments and Lisa Giani Contini for proof-reading. Kristin Fischer, Felix Hugger, Adam Job, Benedikt Kauf, Sebastian Kropp, Luisa Lorenz, Julia Richenhagen, and Leonard Thielmann provided excellent research assistance. 


\section{References}

Arnim, H.H. von (1975). Abgeordnetenentschädigung und Grundgesetz, Karl-Bräuer-Institut des Bundes der Steuerzahler, Wiesbaden.

Arnim, H.H. von (1998). Diener vieler Herren - Die Doppel- und Dreifachversorgung von Politikern, Knaur, München.

Arnim, H.H. von (2010). Die Privilegien von Landespolitikern, Zeitschrift für Rechtspolitik $43,56-57$.

Arnold, F., B. Kauder, and N. Potrafke (2014). Outside earnings, absence, and activity: Evidence from German parliamentarians, European Journal of Political Economy 36, 147-157.

Benito, B. and F. Bastida (2009). Budget transparency, fiscal performance, and political turnout: An international approach, Public Administration Review 69, 403-417.

Benito, B., F. Bastida, A.-M. Ríos, and C. Vicente (2014). The causes of legal rents extraction: Evidence from Spanish municipalities, Public Choice 161, 367-383.

Berger, H. and U. Woitek (1997). Searching for political business cycles in Germany, Public Choice 91, 179-197.

Besley, T. (2004). Paying politicians: Theory and evidence, Journal of the European Economic Association 2, 193-215.

Boone, C., A. Dube, and E. Kaplan (2014). The political economy of discretionary spending: Evidence from the American Recovery and Reinvestment Act, Brookings Papers on Economic Activity, Spring 2014, 375-441.

Bordignon, M., M. Gamalerio, and G. Turati (2013). Decentralization, vertical fiscal imbalance, and political selection, CESifo Working Paper 4459.

Borjas, G. (1984). Electoral cycles and the earnings of federal bureaucrats, Economic Inquiry $22,447-459$.

Bove, V., G. Efthyvoulou, and A. Navas (in press). Political cycles in public expenditure: Butter vs guns, Journal of Comparative Economics.

Braendle, T. (2015). Does remuneration affect the discipline and the selection of politicians? Evidence from pay harmonization in the European Parliament, Public Choice 162, 124.

Caselli, F. and M. Morelli (2004). Bad politicians, Journal of Public Economics 88, 759-782.

Castro, V. and R. Martins (2016). Politically driven cycles in fiscal policy: In depth analysis of the functional components of government expenditures, NIPE Working Paper 02. 
Dalle Nogare, C. and B. Kauder (2016). Term limits for mayors and intergovernmental grants: Evidence from Italian cities, unpublished paper.

De Haan, J. and J. Klomp (2013). Conditional political budget cycles: A review of recent evidence, Public Choice 157, 387-410.

Di Tella, R. and R. Fisman (2004). Are politicians really paid like bureaucrats? Journal of Law and Economics 47, 477-513.

Efthyvoulou, G. (2011). Political cycles under external economic constraints: Evidence from Cyprus, Journal of Economics and Business 63, 638-662.

Efthyvoulou, G. (2012). Political budget cycles in the European Union and the impact of political pressures, Public Choice 153, 295-327.

Eggers, A.C. and J. Hainmueller (2009). MPs for sale? Returns to office in postwar British politics, American Political Science Review 103, 513-533.

Elliott, R.F., D. Bell, A. Scott, A. Ma, and E. Roberts (2005). Devolved government and public sector pay reform: Considerations of equity and efficiency, Regional Studies 39, 519-539.

Fisman, R., N. Harmon, E. Kamenica, and I. Munk (2013). Labor supply of politicians, NBER Working Paper 17726.

Fisman, R., F. Schulz, and V. Vig (2014). The private returns to public office, Journal of Political Economy 122, 806-862.

Foremny, D., R. Freier, M.-D. Moessinger, and M. Yeter (2014). Overlapping political budget cycles in the legislative and the executive, ZEW Discussion Paper 14-099.

Foremny, D. and N. Riedel (2014). Business taxes and the electoral cycle, Journal of Public Economics 115, 48-61.

Gagliarducci, S. and T. Nannicini (2013). Do better paid politicians perform better? Disentangling incentives from selection, Journal of the European Economic Association 11, 369-398.

Gagliarducci, S., T. Nannicini, and P. Naticchioni (2010). Moonlighting politicians, Journal of Public Economics 94, 688-699.

Garmann, S. (in press). Electoral cycles in public administration decisions: Evidence from German municipalities, Regional Studies.

Gersbach, H. (2009). Competition of politicians for wages and office, Social Choice and Welfare 33, 51-71.

Geys, B. (2013). Election cycles in MPs' outside interests? The UK House of Commons, 2005-2010, Political Studies 61, 462-472. 
Geys, B. and K. Mause (in press). The limits of electoral control: Evidence from last-term politicians, Legislative Studies Quarterly.

Herwatz, H. and B. Theilen (2014). Health care and ideology: A reconsideration of political determinants of public healthcare funding in the OECD, Health Economics 23, 225240.

Hillman, A.L. (2015). Rent seeking as political economy, in R.D. Congleton and A.L. Hillman (Eds.), Companion to the Political Economy of Rent Seeking, Edward Elgar, Cheltenham, 10-16.

Huber, P.J. (1967). The behavior of maximum likelihood estimates under nonstandard conditions, Proceedings of the Fifth Berkeley Symposium on Mathematical Statistics and Probability, 221-233.

Jäger, K. (2016). The role of regime type in the political economy of foreign reserve accumulation, European Journal of Political Economy 44, 79-96.

Katsimi, M. and V. Sarantides (2012). Do elections affect the composition of fiscal policy in developed, established democracies? Public Choice 151, 325-362.

Katsimi, M. and V. Sarantides (2015). Public investment and reelection prospects in developed countries, Southern Economic Journal 82, 471-500.

Kauder, B. and N. Potrafke (2013). Government ideology and tuition fee policy: Evidence from the German states, CESifo Economic Studies 29, 628-649.

Kauder, B. and N. Potrafke (2015). Just hire your spouse! Evidence from a political scandal in Bavaria, European Journal of Political Economy 38, 42-54.

Kauder, B. and N. Potrafke (2016). Supermajorities and political rent extraction, Kyklos 68, 65-81.

Kauder, B., N. Potrafke, and C. Schinke (2016). Manipulating fiscal forecasts: Evidence from the German states, unpublished paper.

Keane, M.P. and A. Merlo (2010). Money, political ambition, and the career decisions of politicians, American Economic Journal: Microeconomics 2, 186-215.

Klein, F.A. and S.N. Sakurai (2015). Term limits and political budget cycles at the local level: Evidence from a young democracy, European Journal of Political Economy 37, 21-36.

Klomp, J. and J. de Haan (2013). Political budget cycles and election outcomes, Public Choice 157, 245-267.

Köppl-Turyna, M., G. Kula, A. Balmas, and K. Waclawska (2016). The effects of fiscal decentralization on the strength of political budget cycles in local expenditure, Local Government Studies 42, 785-820. 
Kotakorpi, K. and P. Poutvaara (2011). Pay for politicians and candidate selection: An empirical analysis, Journal of Public Economics 95, 877-885.

Kotakorpi, K., P. Poutvaara, and M. Terviö (2015). Returns to office in national and local politics, unpublished paper.

Luechinger, S., M. Schelker, and A. Stutzer (2014). Governance, bureaucratic rents, and wellbeing differentials across US states, Oxford Economic Papers 66, 443-464.

Matschke, X. (2003). Are there election cycles in wage agreements? An analysis of German public employees, Public Choice 114, 103-135.

Mattozzi, A. and A. Merlo (2008). Political careers or career politicians? Journal of Public Economics 92, 597-608.

Mause, K. (2014). Self-serving legislators? An analysis of the salary-setting institutions of 27 EU parliaments, Constitutional Political Economy 25, 154-176.

Mechtel, M. and N. Potrafke (2013). Electoral cycles in active labor market policies, Public Choice 156, 181-194.

Messner, M. and M.K. Polborn (2004). Paying politicians, Journal of Public Economics 88, 2423-2445.

Mirhosseini, M.R. (2016). Optimal wages for politicians, Southern Economic Journal 82, 1004-1020.

Mocan, N. and D.T. Altindag (2013). Salaries and work effort: An analysis of the European Union parliamentarians, Economic Journal 123, 1130-1167.

Nordhaus, W.D. (1975). The political business cycle, Review of Economic Studies 42, 169190.

Osterloh, S. (2012). Words speak louder than actions: The impact of politics on economic performance, Journal of Comparative Economics 40, 318-336.

Peichl, A., N. Pestel, and S. Siegloch (2013). The politicians' wage gap: Insights from German members of parliament, Public Choice 156, 653-676.

Potrafke, N. (2010). The growth of public health expenditures in OECD countries: Do government ideology and electoral motives matter? Journal of Health Economics 29, 797-810.

Potrafke, N. (2012a). Political cycles and economic performance in OECD countries: Empirical evidence from 1951-2006, Public Choice 150, 155-179.

Potrafke, N. (2012b). Is German domestic social policy politically controversial? Public Choice 153, 393-418.

Potrafke, N., M. Riem, and C. Schinke (2016). Debt brakes in the German states: Governments' rhetoric and actions, German Economic Review 17, 253-275. 
Potrafke, N. and F. Roesel (2016). Political business cycles in health care supply, unpublished paper.

Querubin, P. and J.M. Snyder, Jr. (2013). The control of politicians in normal times and times of crisis: Wealth accumulation by U.S. congressmen, 1850-1880, Quarterly Journal of Political Science 8, 409-450.

Reischmann, M. (2016). Creative accounting and electoral motives: Evidence from OECD countries, Journal of Comparative Economics 44, 243-257.

Riem, M. (2016a). Corporate investment decisions under political uncertainty, unpublished paper

Riem, M. (2016b). Does political uncertainty influence firm owners' business perceptions? Unpublished paper

Rogoff, K. and A. Sibert (1988). Elections and macroeconomic policy cycles, Review of Economic Studies 55, 1-16.

Schneider, C. (2010). Fighting with one hand tied behind the back: Political budget cycles in the West German states, Public Choice 142, 125-150.

Svaleryd, H. and J. Vlachos (2009). Political rents in a non-corrupt democracy, Journal of Public Economics 93, 355-372.

Tepe, M. and P. Vanhuysse (2009). Educational business cycles, Public Choice 139, 61-82.

Tepe, M. and P. Vanhuysse (2013). Cops for hire? The political economy of police employment in the German states, Journal of Public Policy 33, 165-199.

Tepe, M. and P. Vanhuysse (2014). A vote at the opera? The political economy of public theaters and orchestras in the German states, European Journal of Political Economy $36,254-273$.

Vadlamannati, K.C. (2015). Fighting corruption or elections? The politics of anti-corruption policies in India: A subnational study, Journal of Comparative Economics 43, 10351052.

Weichold, J. (2001). Der Abgeordnete und die Diäten. Zum verfassungsrechtlichen Problem der „,angemessenen“, die „Unabhängigkeit“ des Abgeordneten sichernden Entschädigung, UTOPIE kreativ 125, 232-241.

White, H. (1980). A heteroskedasticity-consistent covariance matrix estimator and a direct test for heteroskedasticity, Econometrica 48, 817-838. 
Figure 1: MPs' salaries increase somewhat less in post-election and in pre-election periods

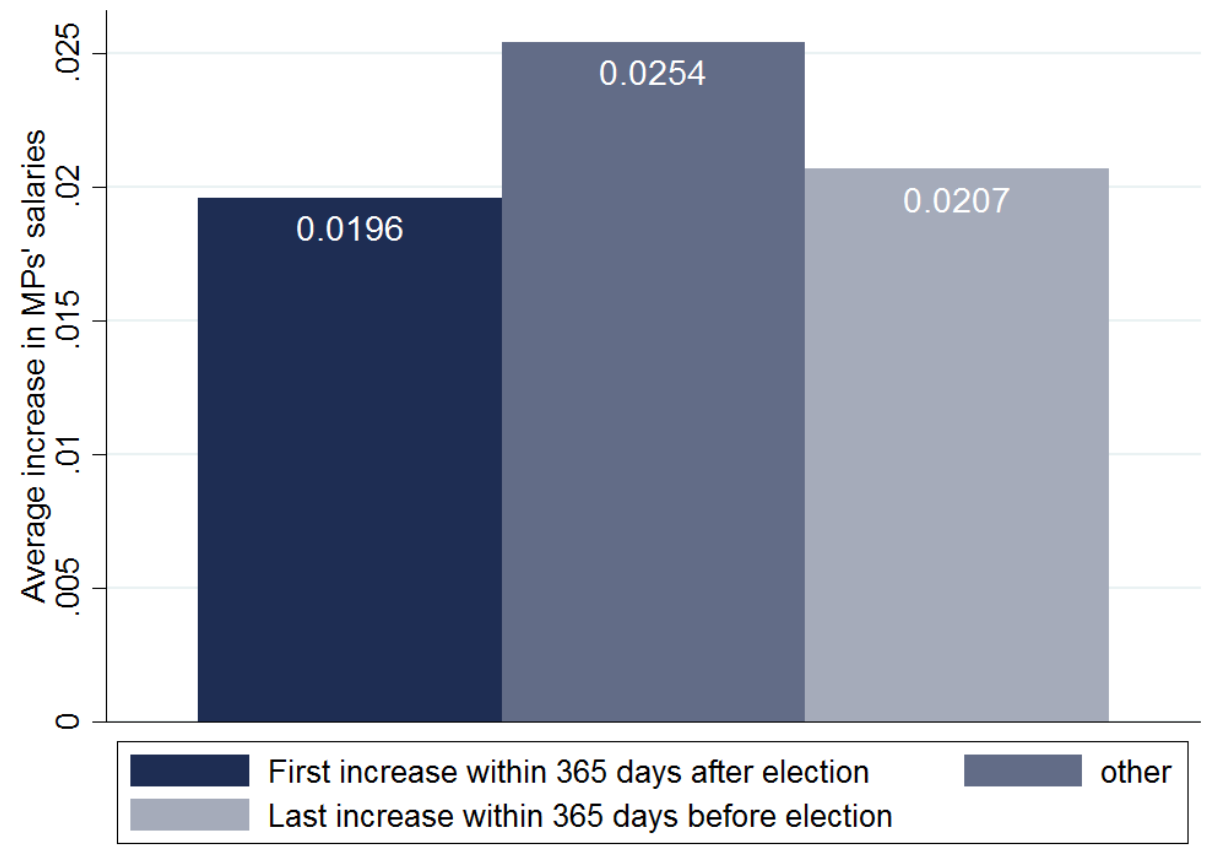

Source: Own illustration.

Figure 2: Increases in MPs' salaries are somewhat lower at the beginning and the end of a legislative period - non-parametric regression (no control variables) and semi-parametric regression (including control variables)

(a) Non-parametric

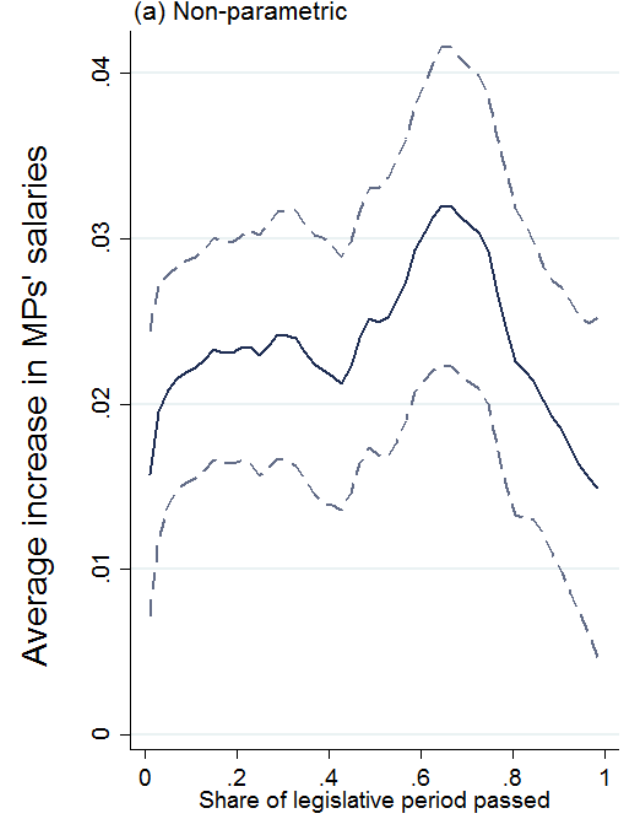

(b) Semi-parametric

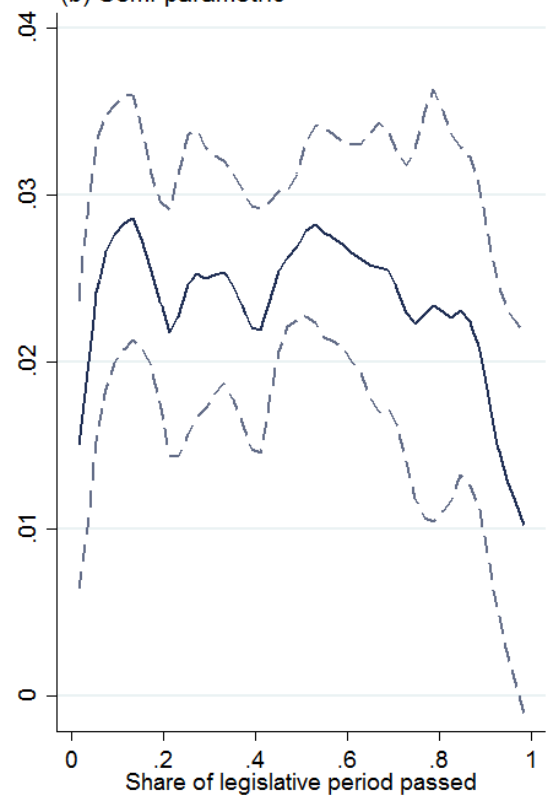

Dashed lines describe 5 percent confidence intervals (standard errors are bootstrapped with 100 replications). The weighted local polynomial estimates are calculated with the Epanechnikov kernel function with a rule-ofthumb bandwidth estimator. The parametric components are differenced out using the Yatchew method. Source: Own illustration. 
Figure 3: MPs' and employees' salaries show similar trends

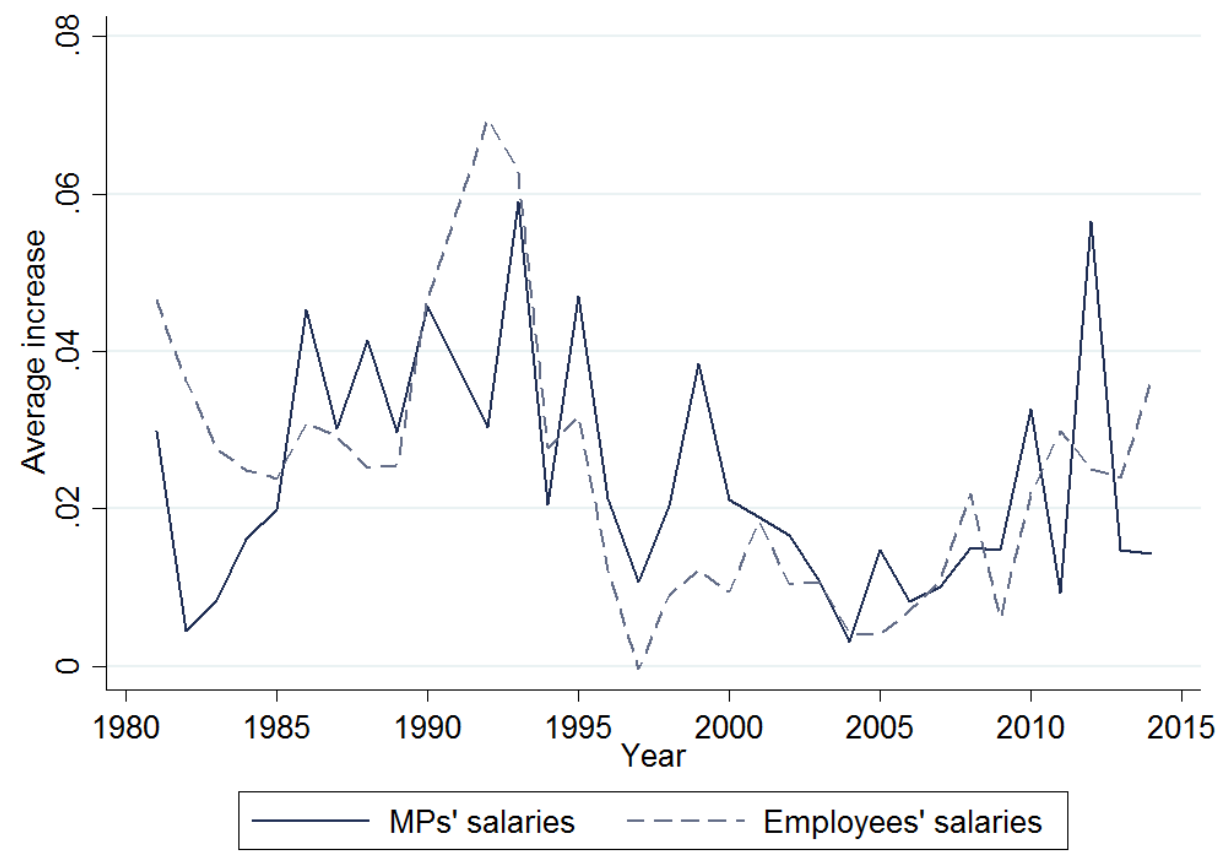

The peak in the increase in employees' salaries in the early 1990s results from the German reunification. Source: Own illustration. 
Table 1: Descriptive statistics

\begin{tabular}{lrrrrr}
\hline & Obs. & Mean & Std. Dev. & Min & Max \\
\hline Increase in MPs' salaries & 367 & 0.024 & 0.036 & 0 & 0.200 \\
Post-election period & 367 & 0.183 & 0.387 & 0 & 1 \\
Pre-election period & 367 & 0.163 & 0.370 & 0 & 1 \\
Share of legislative period passed & 367 & 0.476 & 0.279 & 0.012 & 0.985 \\
Share of legislative period passed (squared) & 367 & 0.304 & 0.283 & 0.0001 & 0.971 \\
Increase in employees' salaries (t-1) & 367 & 0.029 & 0.037 & -0.058 & 0.304 \\
Deficit ratio (t-1) & 367 & 0.015 & 0.026 & -0.226 & 0.276 \\
Government ideology & 367 & 0.559 & 0.454 & 0 & 1 \\
Seat share government & 367 & 0.571 & 0.082 & 0.405 & 0.890 \\
Increase in federal MPs' salaries (t-1) & 367 & 0.023 & 0.022 & 0 & 0.090 \\
\hline
\end{tabular}

The seat share of a government is below 50 percent in the case of a minority government.

Table 2: Correlation between the main variables

\begin{tabular}{lrrrrr}
\hline & $\begin{array}{r}\text { Increase in } \\
\text { MPs' } \\
\text { salaries }\end{array}$ & $\begin{array}{r}\text { Post- } \\
\text { election } \\
\text { period }\end{array}$ & $\begin{array}{r}\text { Pre- } \\
\text { election } \\
\text { period }\end{array}$ & $\begin{array}{r}\text { Share of } \\
\text { legislative } \\
\text { period } \\
\text { passed }\end{array}$ & $\begin{array}{r}\text { Increase in } \\
\text { employees' } \\
\text { salaries } \\
(\mathrm{t}-1)\end{array}$ \\
\hline Increase in MPs' salaries & 1 & & & & \\
Post-election period & -0.054 & 1 & & & \\
Pre-election period & -0.037 & -0.190 & 1 & 1 & \\
Share of legislative period passed & 0.016 & -0.606 & 0.625 & 1 \\
Increase in employees' salaries (t-1) & 0.344 & -0.042 & -0.029 & 0.073 & \\
\hline
\end{tabular}


Table 3: Regression results with election period dummies - excluding fixed time effects. Dependent variable: Increase in MPs' salaries (growth rate). Fixed-effects model with standard errors robust to heteroskedasticity (Huber/White/sandwich standard errors)

\begin{tabular}{lccc}
\hline & $(1)$ & $(2)$ & $(3)$ \\
\hline Post-election period & -0.00422 & -0.00368 & -0.00419 \\
& $(0.00462)$ & $(0.00467)$ & $(0.00461)$ \\
Pre-election period & -0.00422 & -0.00351 & -0.00354 \\
& $(0.00689)$ & $(0.00688)$ & $(0.00692)$ \\
Increase in employees' & & $0.300^{* * *}$ & $0.296^{* * *}$ \\
salaries (t-1) & & $(0.0600)$ & $(0.0615)$ \\
Deficit ratio (t-1) & & -0.0679 & -0.0770 \\
& & $(0.0681)$ & $(0.0695)$ \\
Government ideology & & & 0.000638 \\
& & & $(0.00415)$ \\
Seat share government & & & $-0.0218^{*}$ \\
& & & $(0.0116)$ \\
Increase in federal MPs' & & & 0.131 \\
salaries (t-1) & $0.0252^{* * *}$ & $0.0171^{* * *}$ & $(0.0943)$ \\
Constant & $(0.00151)$ & $(0.00158)$ & $\left(0.00965^{* *}\right.$ \\
& - & - & - \\
Fixed time effects & 373 & 367 & 367 \\
\hline Observations & 15 & 15 & 15 \\
Groups & 0.00330 & 0.0950 & 0.104 \\
$\mathrm{R}^{2}$ within & 0.0550 & 0.859 & 0.826 \\
$\mathrm{R}^{2}$ between & 0.00344 & 0.121 & 0.126 \\
$\mathrm{R}^{2}$ overall & & &
\end{tabular}


Table 4: Regression results with election period dummies - including fixed time effects. Dependent variable: Increase in MPs' salaries (growth rate). Fixed-effects model with standard errors robust to heteroskedasticity (Huber/White/sandwich standard errors)

\begin{tabular}{lccc}
\hline & $(1)$ & $(2)$ & $(3)$ \\
\hline Post-election period & -0.00442 & -0.00504 & -0.00487 \\
& $(0.00439)$ & $(0.00481)$ & $(0.00483)$ \\
Pre-election period & -0.00678 & -0.00735 & -0.00726 \\
& $(0.00747)$ & $(0.00811)$ & $(0.00816)$ \\
Increase in employees' & & $0.364 * * *$ & $0.355^{* * *}$ \\
salaries (t-1) & & $(0.0899)$ & $(0.0918)$ \\
Deficit ratio (t-1) & & -0.0595 & -0.0596 \\
& & $(0.0581)$ & $(0.0576)$ \\
Government ideology & & & -0.00117 \\
& & & $(0.00450)$ \\
Seat share government & & & -0.0168 \\
& 0.0137 & 0.00543 & $(0.0168)$ \\
Constant & $(0.0112)$ & $(0.0107)$ & 0.0172 \\
& Yes & Yes & Yes \\
Fixed time effects & 373 & 367 & 367 \\
Observations & 15 & 15 & 15 \\
Groups & 0.184 & 0.249 & 0.250 \\
$\mathrm{R}^{2}$ within & 0.0193 & 0.800 & 0.792 \\
$\mathrm{R}^{2}$ between & 0.158 & 0.263 & 0.263 \\
$\mathrm{R}^{2}$ overall & & & \\
\hline Strat & & &
\end{tabular}

Standard errors in parentheses; $* * * p<0.01$ 
Table 5: Regression results with continuous time variable - excluding fixed time effects.

Dependent variable: Increase in MPs' salaries (growth rate). Fixed-effects model with standard errors robust to heteroskedasticity (Huber/White/sandwich standard errors)

\begin{tabular}{lcccccc}
\hline & $(1)$ & $(2)$ & $(3)$ & $(4)$ & $(5)$ & $(6)$ \\
\hline Share of legislative & 0.000261 & -0.00165 & -0.00114 & 0.0373 & 0.0362 & 0.0364 \\
period passed & $(0.00588)$ & $(0.00676)$ & $(0.00728)$ & $(0.0221)$ & $(0.0236)$ & $(0.0228)$ \\
Share of legislative & & & & -0.0377 & -0.0383 & -0.0380 \\
period passed (squared) & & & & $(0.0239)$ & $(0.0266)$ & $(0.0262)$ \\
Increase in employees' & & $0.305^{* * *}$ & $0.300^{* * *}$ & & $0.301 * * *$ & $0.296^{* * *}$ \\
salaries (t-1) & & $(0.0605)$ & $(0.0619)$ & & $(0.0616)$ & $(0.0629)$ \\
Deficit ratio (t-1) & & -0.0706 & -0.0796 & & -0.0700 & -0.0789 \\
& & $(0.0685)$ & $(0.0697)$ & & $(0.0694)$ & $(0.0710)$ \\
Government ideology & & & 0.000571 & & & 0.000210 \\
& & & $(0.00405)$ & & & $(0.00424)$ \\
Seat share government & & & $-0.0224 *$ & & & $-0.0223^{*}$ \\
& & & $(0.0115)$ & & & $(0.0113)$ \\
Increase in federal MPs & & & 0.125 & & & 0.126 \\
salaries (t-1) & & $(0.0953)$ & & & $(0.0972)$ \\
Constant & $0.0236^{* * *}$ & $0.0165^{* * *}$ & $0.0262^{* *}$ & $0.0174 * * *$ & $0.0103 * *$ & $0.0201^{* *}$ \\
& $(0.00278)$ & $(0.00291)$ & $(0.00958)$ & $(0.00388)$ & $(0.00435)$ & $(0.00725)$ \\
Fixed time effects & - & - & - & - & - & - \\
\hline Observations & 373 & 367 & 367 & 373 & 367 & 367 \\
Groups & 15 & 15 & 15 & 15 & 15 & 15 \\
$\mathrm{R}^{2}$ within & 0.0000042 & 0.0927 & 0.101 & 0.00534 & 0.0984 & 0.107 \\
$\mathrm{R}^{2}$ between & 0.0759 & 0.845 & 0.807 & 0.643 & 0.858 & 0.827 \\
$\mathrm{R}^{2}$ overall & 0.0000574 & 0.119 & 0.123 & 0.00837 & 0.126 & 0.130 \\
\hline
\end{tabular}

Standard errors in parentheses; * $p<0.10$, ** $p<0.05$, *** $p<0.01$ 
Table 6: Regression results with continuous time variable - including fixed time effects.

Dependent variable: Increase in MPs' salaries (growth rate). Fixed-effects model with standard errors robust to heteroskedasticity (Huber/White/sandwich standard errors)

\begin{tabular}{lcccccc}
\hline & $(1)$ & $(2)$ & $(3)$ & $(4)$ & $(5)$ & $(6)$ \\
\hline Share of legislative & -0.00386 & -0.00410 & -0.00431 & 0.0386 & 0.0481 & 0.0478 \\
period passed & $(0.00653)$ & $(0.00682)$ & $(0.00694)$ & $(0.0244)$ & $(0.0296)$ & $(0.0293)$ \\
Share of legislative & & & & -0.0431 & -0.0528 & -0.0528 \\
period passed (squared) & & & & $(0.0286)$ & $(0.0345)$ & $(0.0344)$ \\
Increase in employees' & & $0.365^{* * *}$ & $0.356^{* * *}$ & & $0.368^{* * *}$ & $0.357^{* * *}$ \\
salaries (t-1) & & $(0.0885)$ & $(0.0904)$ & & $(0.0918)$ & $(0.0933)$ \\
Deficit ratio (t-1) & & -0.0612 & -0.0613 & & -0.0632 & -0.0629 \\
& & $(0.0579)$ & $(0.0574)$ & & $(0.0583)$ & $(0.0581)$ \\
Government ideology & & & -0.00142 & & & -0.00187 \\
& & & $(0.00427)$ & & & $(0.00447)$ \\
Seat share government & & & -0.0195 & & & -0.0186 \\
& & $(0.0174)$ & & & $(0.0163)$ \\
Constant & 0.0156 & 0.00738 & 0.0213 & 0.00621 & -0.00418 & 0.00947 \\
& $(0.0108)$ & $(0.00991)$ & $(0.0141)$ & $(0.0144)$ & $(0.0148)$ & $(0.0148)$ \\
Fixed time effects & Yes & Yes & Yes & Yes & Yes & Yes \\
\hline Observations & 373 & 367 & 367 & 373 & 367 & 367 \\
Groups & 15 & 15 & 15 & 15 & 15 & 15 \\
$\mathrm{R}^{2}$ within & 0.179 & 0.243 & 0.244 & 0.185 & 0.252 & 0.254 \\
$\mathrm{R}^{2}$ between & 0.0288 & 0.797 & 0.788 & 0.00334 & 0.810 & 0.805 \\
$\mathrm{R}^{2}$ overall & 0.153 & 0.258 & 0.259 & 0.162 & 0.269 & 0.270 \\
\hline Strat
\end{tabular}

Standard errors in parentheses; $* * * p<0.01$ 
Table 7: Regression results including indexed years.

Dependent variable: Increase in MPs' salaries (growth rate). Fixed-effects model with standard errors robust to heteroskedasticity (Huber/White/sandwich standard errors)

\begin{tabular}{lcccccc}
\hline & $(1)$ & $(2)$ & $(3)$ & $(4)$ & $(5)$ & $(6)$ \\
\hline Post-election period & -0.00144 & -0.00264 & & & & \\
& $(0.00423)$ & $(0.00433)$ & & & & \\
Pre-election period & -0.00157 & -0.00433 & & & & \\
& $(0.00575)$ & $(0.00601)$ & & & & \\
Share of legislative & & & -0.000253 & -0.00140 & 0.0186 & 0.0196 \\
period passed & & & $(0.00513)$ & $(0.00433)$ & $(0.0159)$ & $(0.0192)$ \\
Share of legislative & & & & & -0.0189 & -0.0210 \\
period passed (squared) & & & & $(0.0171)$ & $(0.0214)$ \\
Increase in employees' & $0.269^{* * *}$ & $0.318^{* *}$ & $0.270^{* * *}$ & $0.318 * *$ & $0.267 * * *$ & $0.317 * *$ \\
salaries (t-1) & $(0.0686)$ & $(0.112)$ & $(0.0679)$ & $(0.111)$ & $(0.0685)$ & $(0.113)$ \\
Deficit (t-1) & -0.0418 & -0.0496 & -0.0429 & -0.0498 & -0.0437 & -0.0503 \\
& $(0.0513)$ & $(0.0559)$ & $(0.0506)$ & $(0.0558)$ & $(0.0513)$ & $(0.0558)$ \\
Government ideology & 0.000392 & -0.00113 & 0.000430 & -0.00110 & 0.0000734 & -0.00149 \\
& $(0.00322)$ & $(0.00336)$ & $(0.00321)$ & $(0.00331)$ & $(0.00332)$ & $(0.00346)$ \\
Seat share government & -0.0152 & -0.0158 & -0.0150 & -0.0155 & -0.0151 & -0.0157 \\
& $(0.00965)$ & $(0.0123)$ & $(0.00953)$ & $(0.0124)$ & $(0.00954)$ & $(0.0126)$ \\
Increase in federal MPs & 0.105 & & 0.103 & & 0.104 & \\
salaries (t-1) & $(0.0707)$ & & $(0.0744)$ & & $(0.0737)$ & \\
Constant & $0.0225 * * *$ & 0.0160 & $0.0220^{* * *}$ & 0.0158 & $0.0192 * * *$ & 0.0128 \\
& $(0.00724)$ & $(0.00970)$ & $(0.00708)$ & $(0.00964)$ & $(0.00594)$ & $(0.00969)$ \\
Fixed time effects & - & Yes & - & Yes & - & Yes \\
\hline Observations & 478 & 478 & 478 & 478 & 478 & 478 \\
Groups & 16 & 16 & 16 & 16 & 16 & 16 \\
$\mathrm{R}^{2}$ within & 0.0918 & 0.216 & 0.0913 & 0.213 & 0.0935 & 0.215 \\
$\mathrm{R}^{2}$ between & 0.437 & 0.303 & 0.454 & 0.364 & 0.418 & 0.338 \\
$\mathrm{R}^{2}$ overall & 0.0980 & 0.215 & 0.0976 & 0.213 & 0.0998 & 0.216 \\
\hline Stal
\end{tabular}

Standard errors in parentheses; $* * p<0.05, * * * p<0.01$ 
Table 8: Regression results for indexed years.

Dependent variable: Increase in MPs' salaries (growth rate). Fixed-effects model with standard errors robust to heteroskedasticity (Huber/White/sandwich standard errors)

\begin{tabular}{lcccccc}
\hline & $(1)$ & $(2)$ & $(3)$ & $(4)$ & $(5)$ & $(6)$ \\
\hline Post-election period & 0.00805 & 0.00656 & & & & \\
& $(0.0112)$ & $(0.00717)$ & & & & \\
Pre-election period & 0.00634 & 0.00680 & & & & \\
& $(0.00835)$ & $(0.00605)$ & & & & \\
Share of legislative & & & -0.00168 & 0.00215 & -0.0241 & -0.0260 \\
period passed & & & $(0.00288)$ & $(0.00316)$ & $(0.0294)$ & $(0.0252)$ \\
Share of legislative & & & & & 0.0210 & 0.0266 \\
period passed (squared) & & & & $(0.0279)$ & $(0.0233)$ \\
Increase in employees' & 0.0158 & 0.391 & 0.00394 & 0.526 & 0.00584 & 0.444 \\
salaries (t-1) & $(0.0455)$ & $(0.498)$ & $(0.0364)$ & $(0.559)$ & $(0.0321)$ & $(0.518)$ \\
Deficit (t-1) & -0.0496 & -0.199 & -0.0246 & -0.178 & -0.0175 & -0.194 \\
& $(0.116)$ & $(0.147)$ & $(0.0863)$ & $(0.149)$ & $(0.0804)$ & $(0.159)$ \\
Government ideology & 0.00743 & 0.00920 & $0.00540 *$ & 0.00754 & 0.00692 & 0.0106 \\
& $(0.00423)$ & $(0.00656)$ & $(0.00265)$ & $(0.00524)$ & $(0.00410)$ & $(0.00774)$ \\
Seat share government & 0.0144 & 0.0120 & 0.00793 & 0.00410 & 0.00761 & 0.000328 \\
& $(0.0107)$ & $(0.00965)$ & $(0.0129)$ & $(0.0131)$ & $(0.0132)$ & $(0.0144)$ \\
Increase in federal MPs' & -0.00588 & & 0.00840 & & 0.00761 & \\
salaries (t-1) & $(0.0370)$ & & $(0.0364)$ & & $(0.0407)$ & \\
Constant & 0.00615 & -0.0110 & $0.0138^{* *}$ & -0.00782 & $0.0171 *$ & -0.00139 \\
& $(0.00806)$ & $(0.0165)$ & $(0.00609)$ & $(0.0157)$ & $(0.00871)$ & $(0.0129)$ \\
Fixed time effects & - & Yes & - & Yes & - & Yes \\
\hline Observations & 111 & 111 & 111 & 111 & 111 & 111 \\
Groups & 12 & 12 & 12 & 12 & 12 & 12 \\
$\mathrm{R}^{2}$ within & 0.0386 & 0.290 & 0.00854 & 0.270 & 0.0195 & 0.283 \\
$\mathrm{R}^{2}$ between & 0.00556 & 0.00346 & 0.0273 & 0.00395 & 0.0635 & 0.0104 \\
$\mathrm{R}^{2}$ overall & 0.0428 & 0.272 & 0.0137 & 0.248 & 0.0198 & 0.264 \\
\hline Standard errors in parenthes
\end{tabular}

Standard errors in parentheses; $* p<0.10$, ** $p<0.05$ 